\title{
ПОБУДОВА СТРУКТУРИ ОНТОЛОГІЇ ДІАГНОСТИЧНОГО ТА ЛІКУВАЛЬНОГО ПРОЦЕСІВ
}

В. В Краснов

\author{
Національна медична академія післядипломної освіти імені П. А.Шупика
}

\begin{abstract}
Представлено структуру онтології діагностичного і лікувального процесів. Обґрунтовано поняття спрямованості онтології медичних процедурних знань. Описано процедурні й декларативні концепти і представлена трирівнева схема онтології діагностичного й лікувального процесів
\end{abstract}

Ключові слова: онтологія діагностичних і лікувальних процесів, процедурні знання, декларативні знання.

\section{ПОСТРОЕНИЕ СТРУКТУРЫ ОНТОЛОГИИ ДИАГНОСТИЧЕСКОГО И ЛЕЧЕБНОГО ПРОЦЕССОВ}

В. В. Краснов

\begin{abstract}
Национальная медицинская академия последипломного образования имени П. А. Шупика
\end{abstract}
\begin{abstract}
Представлена структура онтологии диагностического и лечебного процессов. Введено понятие направленности онтологии медицинских процедурных знаний. Описаны процедурные и декларативные концепты и предложена трехуровневая схема онтологии диагностического и лечебного процессов.
\end{abstract}

Ключевые слова: онтология диагностических и лечебных процессов, процедурные знания, декларативные знания.

\section{CONSTRUCTION OF ONTOLOGICAL STRUCTURE OF DIAGNOSTIC AND MEDICAL PROCESSES}

\author{
V. V. Krasnov \\ National Medical Academy of Post-Graduate Education by P. L. Shupyk
}

\begin{abstract}
The structure of the ontology of diagnostic and medical processes is offered. The concept of an ontology orientation of medical procedural knowledge is proved. Procedural and declarative concepts are described. Three-level ontological scheme of diagnostic and medical processes is offered.
\end{abstract}

Key words: ontology diagnostic and medical processes, procedural knowledge, declarative knowledge.

Вступ. Сьогодні, при описі предметних галузей, все більшою популярністю користуються методи інженерії знань, серед яких онтології займають провідні позиції. Саме тому дослідники приділяють багато уваги завданню створення таких онтологій, які найточніше відображатимуть властивості й структуру предметної галузі, а також взаємодію іiї складових $[1,2]$.

У літературі досить добре представлені принципи розробки онтології декларативних знань $[3,4]$, але система підготовки лікарів усе гостріше потребує опису алгоритмів медичних дій, на підставі яких повинні формуватися вміння лікарів. У свою чергу, процесні складові алгоритмів дій засновані здебільшого на процедурних знаннях. Таким чином, здобувають високу актуальність завдання розробки онтології медичних процесів.

Мета. Створити структуру онтологічного опису діагностичних і лікувальних процесів.

Основна частина. Під онтологічною моделлю (онтологією) діагностичних і лікувальних процесів у даній роботі розуміється знакова система $O=(X, R$, $\left.A, F_{A}\right)$, де

$X$ - кінцева множина понять (концептів) діагностичних/лікувальних знань (предметної галузі);

$\mathrm{R}$ - кінцева множина відносин між концепта

$A$ - аксіоми, які описують обмеження, що накладають на $X$ i R;

$F_{A}$ - кінцева множина функцій інтерпретації для $\mathrm{X}$ i R.

(C) В.В Краснов 
У свою чергу, процеси являють собою набори процедурних і декларативних знань.

При описі онтології медичних процесів, відносини між концептами набувають причинно-наслідкової спрямованості і являють собою відносини часткового порядку, тобто концепт може бути причиною активування дочірнього концепту/концептів або наслідком активації батьківського концепту. Окрім того, поняття процесу прямо залежить від часу, а концепти є подіями.

Онтології медичних процесів описуються наборами концептів X:

- стану елементів системи, що задіяна в процесі;

- концептами, що визначають запуск/зупинення/продовження процесу;

- концептами, що обумовлені наслідками виконання процесів;

- концептами саме процесів.

Нехай $X=\left\{X_{1}, X_{2}, \ldots, X_{n}\right\}$ - множина концептів, елементи якої діляться на два типи: декларативні, які позначатимуться як $X^{d}{ }_{i}$, і процедурні - $X^{p}{ }_{i}$.

Декларативними концептами $\left(X_{i}^{d}\right)$ онтології процесів будемо вважати концепти: станів, наслідків, запуску/ зупинення/продовження процесів.
До процедурних концептів $\left(X^{p}{ }_{i}\right)$ віднесемо сам процес.

Система, що задіяна в процесі, складається із двох взаємозалежних складових: система, на яку впливають, і система, що впливає. Онтологічні відноси$н и \mathfrak{R}$ процесів визначаються саме цими впливами. В описі відносин, залежно від суб'єкта (експерта), що визначає відношення, можуть бути використані обидві векторні спрямованості - результуюча (позначимо її як $\Re)$, коли "концепт $X_{i+1}$ з'являється в результаті дії концепту $X_{i}^{\prime \prime}$, та інічіююча (позначимо їі як $\mathfrak{R}^{-1}$ ), коли "концепт $X_{i}$ приводить до появи концепту $X_{i+1}$ ".

Пару концептів, пов'язаних відношенням, будемо описувати в такий спосіб: $\mathfrak{R}_{i}\left(X_{i}\right)=X_{i+1} \Leftrightarrow \mathfrak{R}_{i}\left(X_{i}\right.$ :

$\left.X_{i+1}\right)$, - це означає, що концепт $X_{i}$ вплин концепту $X_{i+1}$. У свою чергу, запис: $\mathfrak{R}^{-1}{ }_{i}\left(X_{i}\right)=X_{i+1}$ $\Leftrightarrow \mathfrak{R}^{-1}{ }_{i}\left(X_{i}, X_{i+1}\right)$ говорить про те, що концепт $X_{i+1}$ актуалізованим у результаті впливу концепту $X_{i}$. Графічно це відображено на рис. 1.

Ще одне обмеження при описі онтології клінічних процесів полягає в тому, що подібна онтологія завжди має чітку спрямованість. Якщо для пар відносин,

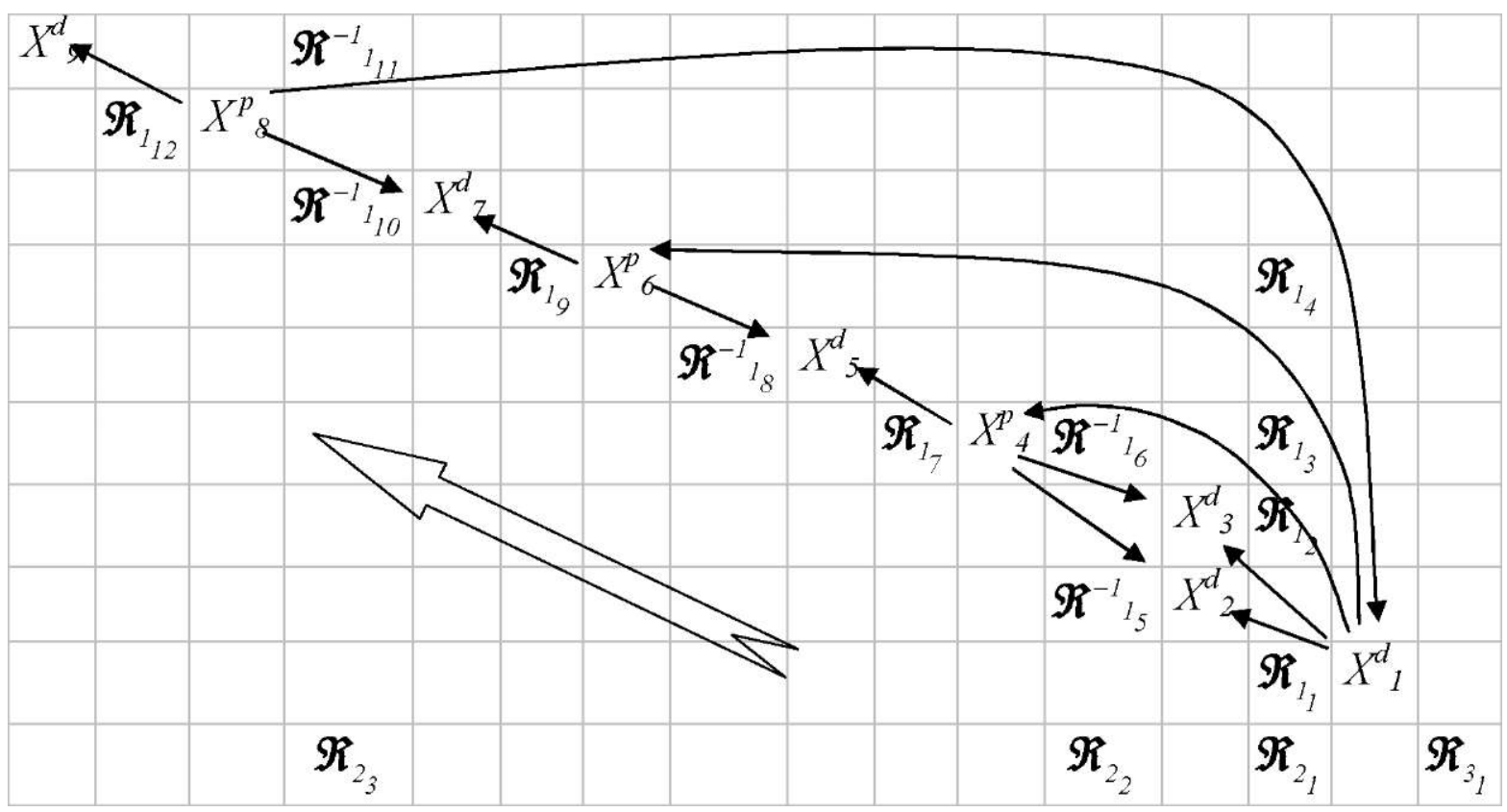

Puc. 1. Схематичне представлення концептів та відношень між ними для трирівневої онтології діагностичного процесу.

що поєднують концепти, вона може бути прямою і зворотною, то для відносин більш високих рівнів тільки прямою.

На елементах $X$ визначені відносини з множиною $\Re$ $=\left\{\Re_{1}, \mathfrak{R}_{2}, \ldots, \mathfrak{R}_{m}\right\}$, тобто кожний кортеж $\left(\mathrm{X}_{\mathrm{i} 1}, \mathrm{X}_{\mathrm{i} 2}, \ldots .\right.$, $\left.X_{i_{k}}\right) \in \mathfrak{R}_{i} \in$ впорядкованим і перестановки елементів кортежу можуть відбуватися тільки за рішенням експерта.

Нехай $\Re_{1_{i}}=\left\{\Re_{2} \subseteq X^{h} \times X^{h+1}\right\}$ - множина бінарних відносин 1 -го рівня, де $i=1, \ldots, s$, порядок концептів строго фіксований і пари утворюються на основі функціональних відносин. 
Нехай $\mathfrak{R}_{2}=\left\{\mathfrak{R}_{2} \subseteq \mathfrak{R}^{i}{ }_{1} \times X^{h}\right\}$, де $\mathfrak{R}_{3_{k}} n$-арне відношення, $i+h=n$.

Аналогічно $\mathfrak{R}_{3}=\left\{\mathfrak{R}_{3_{k}} \subseteq \mathfrak{R}_{2}{ }_{2} \times X^{r}\right\}$, де $\mathfrak{R}_{3_{k}} m$-арне відношення, $l+r=m$.

У випадку, якщо кілька концептів $X_{i}, X_{i+1}, . ., X_{i+n}$ стають причиною виникнення концепту $X_{i+n+1}$, то подібну ситуацію можна записати таким чином. Пари концептів:

$$
\begin{aligned}
& \Re_{1_{1}}\left(X_{i}, X_{i+n+1}\right), \Re_{1_{2}}^{-1}\left(X_{i+1}, X_{i+n+1}\right), \ldots, \mathfrak{R}_{1_{i}}\left(X_{i+n},\right. \\
& \left.X_{i+n+1}\right) \\
& \quad \text { і відношення більш високого рівня, що об'єднує ці } \\
& \text { пари: }
\end{aligned}
$$

$$
\begin{aligned}
& \boldsymbol{R}_{2_{i}}\left(\boldsymbol{\Re}_{1_{1}}\left(X_{i}, X_{i+n+1}\right), \boldsymbol{K}^{-1}{ }_{2}\left(X_{i+1}, X_{i+n+1}\right), \ldots,\right. \\
&\left.\boldsymbol{R}_{1_{i}}\left(X_{i+n}, X_{i+n+1}\right), X_{i+n+1}\right) .
\end{aligned}
$$

Якщо дочірній концепт створюється кількома батьківськими - "збіжні породження", то в такому разі з'являється відношення більш високого рівня. У випадку ж "розбіжних породжень", якщо один батьківський концепт служить причиною виникнення декількох дочірніх, то даний кластер описується просто відповідним набором пар відносин.

Функиія інтерпретації концептів являє собою два підвиди: функція інтерпретації декларативних концептів $\left(F\left(X^{d}\right)\right)$ і функція інтерпретації процедурних концептів $\left(F\left(X^{p}\right)\right)$.

Необхідно пам'ятати, що функція інтерпретації будьякої онтології процесів існує у двох видах, які залежать від ситуації іiі застосування. Функцію інтерпретації онтології можуть задавати як розроблювач, так і споживач цієї онтології.

При цьому розроблювач онтології описує функції інтерпретації очікуваних концептів і відносин. У свою чергу, споживач цієї онтології, застосовуючи ії до реальних процесів, у результаті виконання функції інтерпретації отримує іiї реальні значення залежно від ситуації, в якій дана онтологія застосовувалася.

Слід зазначити, що подібні розбіжності функцій інтерпретації онтології трапляються тільки в результатах виконання процесів, які відбуваються в рамках даної онтології. Це можна пояснити з наступних позицій: розроблювач описує онтологічну модель картини світу. Як показує практика, ця модель, відповідно до принципів Парето, охоплює лише біля 80 \% всіх можливих ситуацій і тому не завжди може бути виражена конкретними значеннями. У подібних випадках розроблювач користується діапазонами, в які попадають до 80 \% всіх очікуваних значень вико- нання процесів. Споживач онтології, у свою чергу, застосовуючи функцію інтерпретації для реальних подій, у результаті виконання процесів отримує їхні реальні значення.

Результатом виконання функції інтерпретаціï декларативних концептів є опис такого стану декларативного концепту, при якому концепт вважається таким, що відбувся (стан концепту дорівнює очікуваному (шаблонному) стану).

Результатом виконання функції інтерпретації процедурних концеептів є опис конкретного процесу з позначенням всіх його атрибутів.

Результатом виконання функції інтерпретації відносин є визначення істинності, хибності або невизначеності конкретного відношення на тих концептах, на яких воно визначено. При цьому важливо відзначити, що функція інтерпретації відносин набуває значимість тільки тоді, коли визначаються функції інтерпретації концептів, які входять у відношення, тобто $F\left(\Re_{1_{i}}\left(X_{i}, X_{i+1}\right)\right)=\mathscr{R}_{1_{i}}\left(F\left(X_{i}\right), F\left(X_{i+1}\right)\right)$.

У випадку опису конкретних процесів функція інтерпретації дає конкретне значення змісту (наприклад, концепт $X^{d}{ }_{2}$ - ознака, що виміряється, функція інтерпретації концепту $F\left(X_{2}^{d}\right)$ - температура).

Значення при інтерпретації відносин $R_{i}$ визначаються значенням $X$ за допомогою функції інтерпретації $E$ При цьому $F\left(\Re_{i}\right)$ і $F\left(X_{i_{k}}\right)$ - це конкретне наповнення змістовною інформацією відносно $\Re_{i} \mathrm{i} X_{i_{k}}$.

Онтологія діагностичного процесу. Користуючись структурою онтологічного опису, представимо онтологію діагностичного процесу (ДП). Будемо використовувати обгрунтування, зроблені в попередній частині.

Концеепти $X$ діагностичного процесу можуть бути представлені в такий спосіб: $X=\left\{X_{0}^{p}, X^{d}{ }_{1}, X^{d}{ }_{2}, X^{d}{ }_{3}\right.$, $\left.X_{4}^{p}, X^{d}, X^{p}{ }_{6} X^{d}{ }_{7}, X^{p}{ }_{8}, X^{d}{ }_{9}\right\}$, де:

$X^{p}{ }_{i}$ - - роцеедурні концепти деякого унікального ДП: $X^{p}{ }_{0}$ - постановка мети; $X^{p}{ }_{4}$ - отримання інформації; $X^{p}{ }_{6}$ - аналіз отриманої інформації; $X_{8}^{p}$ - висновок (співвіднесення 3 метою) і оформлення медичної документації;

$X^{d}{ }_{i}$ декларативні концепти елементарного блоку ДП: $X^{d}{ }_{1}$ - мета; $X^{d}{ }_{2}$ - ознака, що виміряється; $X^{d}$ - джерело, 3 якого витягується інформація; $X^{d}{ }_{5}$ - вид отриманої інформації; $X^{d}$ - вид інформації, отриманої в результаті аналізу; $X^{d}{ }_{9}$ - результати висновку.

Опишемо спочатку бінарні відносин між наборами концептів (рис. 1) з урахуванням спрямованості дії відносин (табл. 1). 
Таблиця 1. Бінарні відносини між наборами концептів онтології ДП

\begin{tabular}{|c|c|c|}
\hline Відносини & & Опис відносин \\
\hline $\begin{array}{l}\boldsymbol{K}^{-1}{ }_{l_{0}}\left(X_{0}^{p}\right)=X_{1}^{d} \\
\boldsymbol{R}^{-1}{ }_{l_{0}}\left(X_{0}^{p}, X^{d}\right)\end{array}$ & & $\begin{array}{l}\text { Початковою дією ДП є процес визначення мети }\left(X^{p}{ }_{0}\right) \text {. Даний процес виходить } \\
\text { за рамки онтологічної схеми. Результатом }\left(X^{p}{ }_{0}\right) \epsilon \text { задана мета ДП }\left(X^{d}{ }_{1}\right) \text {. } \\
\text { Відношення в цьому випадку зворотне, тобто мета задана процесом визначення } \\
\text { мети. }\end{array}$ \\
\hline $\begin{array}{l}\boldsymbol{R}_{1_{1}}\left(X^{d}{ }_{1}\right)=X^{d} \\
\boldsymbol{R}_{l_{1}}\left(X^{d}{ }_{1}, X^{d}{ }_{2}\right)\end{array}$ & $\Leftrightarrow$ & $\begin{array}{l}\text { У свою чергу, мета }\left(X^{d}{ }_{1}\right) \text { є тим головним фактором, що визначає такі складові } \\
\text { (концепти) ДП, як: } \\
X_{2}^{d} \text { - ознака, що виміряється, }\end{array}$ \\
\hline $\begin{array}{l}\boldsymbol{R}_{l_{2}}\left(X_{1}^{d}\right)=X^{d} \\
\boldsymbol{R}_{l_{2}}\left(X^{d}{ }_{1}, X^{d}{ }_{3}\right)\end{array}$ & $\Leftrightarrow$ & $X_{3}^{d}$ - джерело, з якого витягується інформація; \\
\hline $\begin{array}{l}\boldsymbol{R}_{l_{3}}\left(X^{d}{ }_{1}\right)=X^{p}{ }_{4} \\
\boldsymbol{R}_{l_{3}}\left(X_{1}^{d}, X^{p}{ }_{4}\right)\end{array}$ & & $X_{4}^{p}$ - метод отримання інформації; \\
\hline $\begin{array}{l}\boldsymbol{R}_{1_{4}}\left(X_{1}^{d}\right)=X_{6}^{p} \\
\boldsymbol{R}_{1_{4}}\left(X_{1}^{d}, X_{6}^{p}\right)\end{array}$ & $\Leftrightarrow$ & $X_{6}^{p}$-метод аналізу отриманої інформації. \\
\hline $\begin{array}{l}\boldsymbol{R}^{-1}{ }_{1_{5}}\left(X^{d}{ }_{2}\right)=X^{p}{ }_{4} \\
\boldsymbol{R}^{-1}{ }_{1_{5}}\left(X^{d}{ }_{2}, X^{p}{ }_{4}\right) \\
\boldsymbol{R}^{-1}{ }_{{ }_{6}}\left(X^{d}{ }_{3}\right)=X^{p}{ }_{4} \\
\boldsymbol{R}^{-1}{ }_{{ }_{6}}\left(X^{d}{ }_{3}, X^{p}{ }_{4}\right)\end{array}$ & $\Leftrightarrow$ & $\begin{array}{l}\text { Процес отримання інформації }\left(X^{p}{ }_{4}\right) \text { ініціюється ознакою, що вимірюється }\left(X^{d}{ }_{2}\right) \text { і } \\
\text { джерелом, } 3 \text { якого витягується інформація }\left(X^{d}{ }_{3}\right) \text {. }\end{array}$ \\
\hline $\begin{array}{l}\boldsymbol{R}_{l_{7}}\left(X^{p}{ }_{4}\right)=X^{d} \\
\boldsymbol{R}_{l_{7}}\left(X_{4}^{p}, X^{d}{ }_{5}\right)\end{array}$ & $\Leftrightarrow$ & $\begin{array}{l}\text { У свою чергу, у результаті виконання процесу отримання інформації }\left(X^{p}{ }_{4}\right) \text {, } \\
\text { 3'являється інформація }\left(X^{d}{ }_{5}\right) \text {. }\end{array}$ \\
\hline $\begin{array}{l}\boldsymbol{R}^{-1}{ }_{8}\left(X^{d}{ }_{5}\right)=X_{6}^{p} \\
\boldsymbol{R}^{-1}{ }_{1}\left(X_{5}^{d}, X_{6}^{p}\right)\end{array}$ & $\Leftrightarrow$ & $\begin{array}{l}\text { Процес аналізу отриманої інформації }\left(X_{6}^{p}\right) \text { запускається фактом появи } \\
\text { інформації }\left(X^{d}{ }_{5}\right) \text {. }\end{array}$ \\
\hline $\begin{array}{l}\boldsymbol{R}_{1_{9}}\left(X_{6}^{p}\right)=X_{7}^{d} \\
\boldsymbol{R}_{1_{9}}\left(X_{6}^{p}{ }_{6} X^{d}\right)\end{array}$ & & $\begin{array}{l}\text { У результаті виконання процесу аналізу отриманої інформації }\left(X_{6}^{p}\right) \text { виходить } \\
\text { результат аналізу }\left(X^{d}\right) \text {. }\end{array}$ \\
\hline $\begin{array}{l}\boldsymbol{R}^{-1}{ }_{10}\left(X_{7}^{d}\right)=X_{8}^{p} \\
\boldsymbol{R}^{-1}{ }_{10}\left(X_{7}^{d}, X_{8}^{p}\right)\end{array}$ & $\Leftrightarrow$ & Процес одержання висновку $\left(X_{8}^{p}\right)$ запускається результатом аналізу $\left(X_{7}^{d}\right)$. \\
\hline $\begin{array}{l}\boldsymbol{R}^{-1}{ }_{11}\left(X_{1}^{d}\right)=X_{8}^{p} \\
\boldsymbol{R}^{-1}{ }_{11}\left(X_{1}^{d}, X_{8}^{p}\right)\end{array}$ & $\Leftrightarrow$ & Процес одержання висновку $\left(X^{p}{ }_{8}\right)$ враховує мету ДП $\left(X_{1}^{d}\right)$. \\
\hline $\begin{array}{l}\boldsymbol{R}_{1_{12}}\left(X^{p}{ }_{8}\right)=X_{9}^{d} \\
\boldsymbol{R}_{1_{12}}\left(X_{8}^{p}, X_{9}^{d}\right)\end{array}$ & $\Leftrightarrow$ & $\begin{array}{l}\text { Результатом процесу одержання висновку }\left(X_{8}^{p}\right) \in \text { оформлена документація } \\
\left(X^{d}{ }_{9}\right) \text {. }\end{array}$ \\
\hline
\end{tabular}

Вибір спрямованості відносини при описі онтології визначають експерти.
На другому рівні відносин представимо набори взаємодіючих концептів у такий спосіб. Як було заз- 
начено раніше, процес отримання інформації $\left(X^{p}{ }_{4}\right)$ визначається ознакою, що вимірюється $\left(X^{d}{ }_{2}\right)$ і джерелом, з якого витягується інформація $\left(\mathrm{X}_{3}^{\mathrm{d}}\right)$ :

$$
\begin{aligned}
& \Re^{-1}{ }_{1_{5}}\left(X^{d}{ }_{2}\right)=X^{p}{ }_{4} \Leftrightarrow \Re^{-1}{ }_{1_{5}}\left(X^{d}{ }_{2}, X^{p}{ }_{4}\right) \\
& \boldsymbol{R}_{1_{6}}^{-1}\left(X_{3}^{d}\right)=X_{4}^{p} \Leftrightarrow \boldsymbol{R}^{-1}{ }_{1}\left(X_{3}^{d}, X_{4}^{p}\right)
\end{aligned}
$$

У цьому випадку отримуємо "збіжність" відносин, коли з декількох незалежних концептів шляхом застосування відповідних бінарних відносин випливає один концепт. Звідси відношення другого рівня можна записати як:

$$
\Re_{2_{2}}\left(\Re^{-1}{ }_{15}\left(X^{d}, X^{p}\right), \Re^{-1}{ }_{1}\left(X^{d}{ }_{3}, X^{p}{ }_{4}\right), X^{p}{ }_{4}\right)
$$

Як було визначено раніше, процес одержання висновку $\left(X_{8}^{p}\right)$ враховує мету ДП $\left(X^{d}{ }_{1}\right.$ і він же запускається результатом аналізу $\left(X^{d}{ }_{7}\right)$ :

$$
\begin{gathered}
\boldsymbol{R}^{-1}{ }_{10}\left(X^{d}{ }_{7}\right)=X_{8}^{p} \Leftrightarrow \boldsymbol{R}^{-1}{ }_{10}\left(X^{d}{ }_{7}, X^{p}{ }_{8}\right) \\
\boldsymbol{R}^{-1}{ }_{11}\left(X^{d}{ }_{1}\right)=X_{8}^{p} \Leftrightarrow \boldsymbol{R}^{-1}{ }_{11}\left(X^{d}{ }_{1}, X^{p}{ }_{8}\right)
\end{gathered}
$$

Звідси відношення другого рівня можна записати як:

$$
\boldsymbol{R}_{2_{3}}\left(\boldsymbol{R}^{-1}{ }_{10}\left(X^{d}, X_{8}^{p}\right), \boldsymbol{R}^{-1}{ }_{11}\left(X^{d}{ }_{1}, X_{8}^{p}\right), X_{8}^{p}\right)
$$

Таким чином, повну онтологію ДП можна описати наступною послідовністю: $\boldsymbol{\Re}_{3_{1}}=\left(\boldsymbol{\Re}_{1_{0}}^{-1}, \mathfrak{R}_{1_{1}}, \mathfrak{R}_{1_{2}}\right.$,

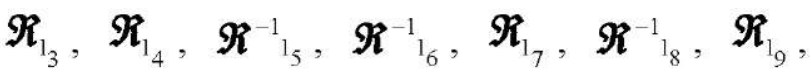
$\left.\boldsymbol{K}_{{ }_{10}}^{-1}, \boldsymbol{R}_{{ }_{11}}^{-1}, \boldsymbol{R}_{1_{12}}\right)$, або $\boldsymbol{R}_{3_{1}}\left(\boldsymbol{R}^{-1}{ }_{1_{0}}\left(X_{0}^{p}, X_{1}^{d}\right)\right.$, $\Re_{1_{1}}\left(X^{d}{ }_{1}, X^{d}\right), \Re_{1_{2}}\left(X^{d}{ }_{1}, X^{d}{ }_{3}\right), \Re_{1_{3}}\left(X^{d}{ }_{1}, X^{p}{ }_{4}\right), \Re_{1_{4}}\left(X^{d}{ }_{1}\right.$,
$\left.X_{6}^{p}\right), \Re_{2_{2}}\left(\Re^{-1}{ }_{1_{5}}\left(X^{d}{ }_{2}, X^{p}{ }_{4}\right), \Re^{-1}{ }_{1_{6}}\left(X^{d}{ }_{3}, X^{p}{ }_{4}\right), X^{p}{ }_{4}\right)$, $\Re_{1_{7}}\left(X^{p}{ }_{4}, X^{d}{ }_{5}\right), \Re_{1_{8}}^{-1}\left(X^{d}{ }_{5}, X^{p}{ }_{6}\right), \mathscr{R}_{1_{9}}\left(X^{p}{ }_{6}, X^{d}{ }_{7}\right)$, $\boldsymbol{R}_{2_{3}}\left(\boldsymbol{K}^{-1}{ }_{10}\left(X^{d}{ }_{7}, X^{p}{ }_{8}\right), \boldsymbol{R}^{-1}{ }_{11}\left(X^{d}{ }_{1}, X^{p}{ }_{8}\right), X^{p}{ }_{8}\right)$, $\left.\boldsymbol{R}_{1_{12}}\left(X^{p}{ }_{8}, X^{d}\right)\right)$.

Онтологія лікувального процесу. Користуючись структурою онтологічного опису, представимо онтологію лікувального процесу (ЛП). Будемо використовувати обгрунтування, зроблені в попередніх розділах.

Концеетти $X$ лікувального процесу можуть бути представлені в такий спосіб: $X=\left\{X^{d}{ }_{1}, X^{d}{ }_{2}, X^{d}{ }_{3}, X^{p}{ }_{4}\right.$, $X^{d}{ }_{5}, X^{p}{ }_{6}, X^{d}, X^{p}{ }_{8}, X^{d}{ }_{9}$, , де:

$X^{p}{ }_{i}$ - процедурні концепти деякого унікального процесу лікувального впливу (ЛВ): $X^{p}{ }_{6}$ - саме ЛП; $X^{p}{ }_{8}$ моніторинг ЛП (при цьому контролюється як сам ЛП (наприклад, швидкість надходження ліків), так і стан організму (параметри, що вимірюються)) з оцінкою якості здійсненого впливу (досягнення мети).

$X^{d}{ }_{i}$-декларативні кон

буде здійснюватися даний ЛП; $X_{2}^{d}$ - правила, за якими буде здійснюватися ЛП; $X^{d}{ }_{3}$ - параметри об'єкта, на який буде здійснюватися ЛВ; $X^{d}{ }_{4}$ - структурні складові ЛП (наприклад, апаратура, видаткові матеріали, персонал тощо); $X^{d}{ }_{5}$ - персонал, що здійснює ЛП; $X^{d}{ }_{7}$ - результати ЛП; $X_{9}^{d}$ - висновок і оформлення медичної документації.

Опишемо спочатку бінарні відносин між наборами концептів (рис. 2) з урахуванням спрямованості дії відносин (табл. 2).

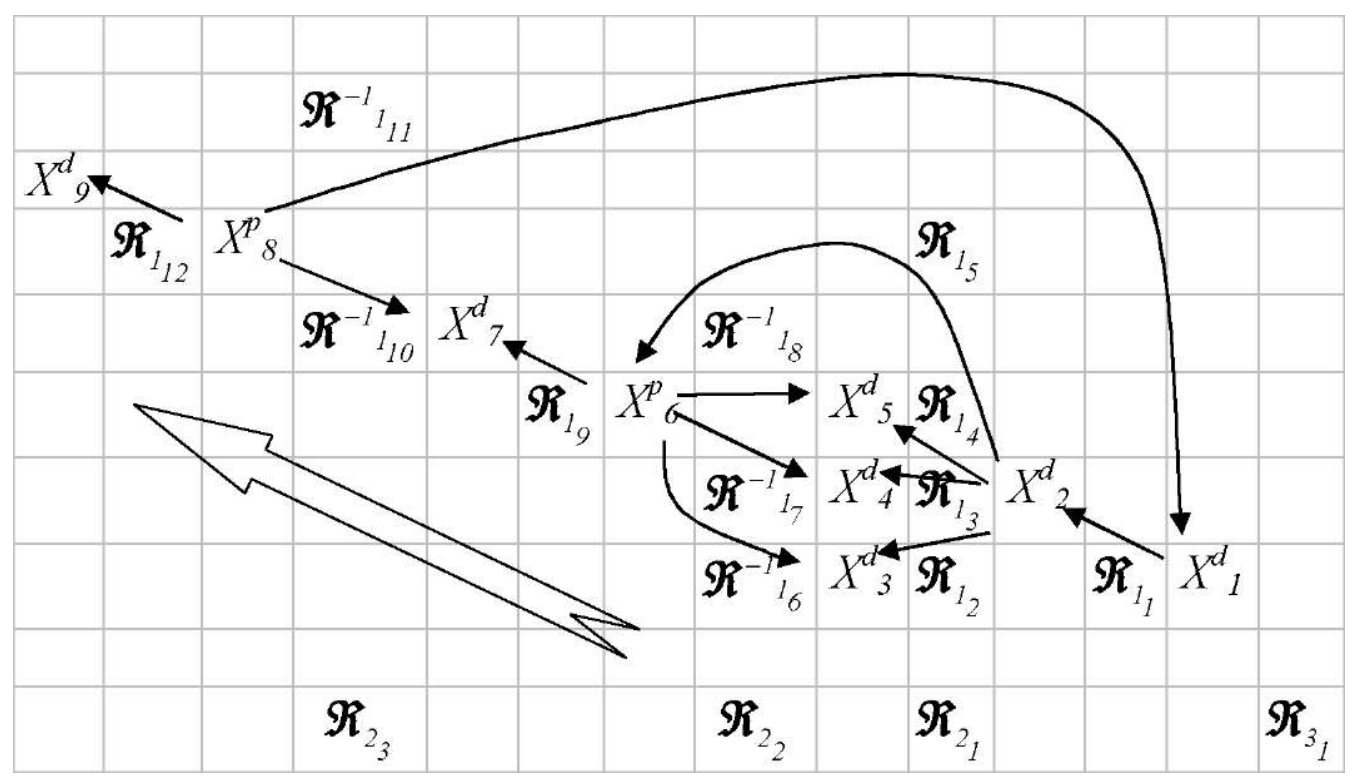

Рис. 2. Схематичне представлення концептів та відношень між ними для трирівневої онтології ЛП. 
Таблиця 2. Бінарні відносини між наборами концептів онтології ЛП

\begin{tabular}{|c|c|}
\hline Відносини & Опис відносин \\
\hline 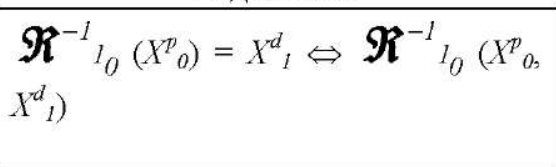 & $\begin{array}{l}\text { Самою початковою дією ЛП є процес визначення мети } X^{p}{ }_{0} \text {. Даний } \\
\text { процес виходить за рамки онтологічної схеми. Результатом } X^{p}{ }_{0} \epsilon \text { задана } \\
\text { мета ЛП }\left(X_{1}^{d}\right) \text {. Відношення в цьому випадку зворотне, тобто мета } \\
\text { задана процесом визначення мети. }\end{array}$ \\
\hline $\boldsymbol{R}_{l_{1}}\left(X^{d}{ }_{1}\right)=X^{d}{ }_{2} \Leftrightarrow \boldsymbol{R}_{l_{1}}\left(X^{d}{ }_{1}, X^{d}{ }_{2}\right)$ & $\begin{array}{l}\text { У свою чергу, мета }\left(X^{d}{ }_{1}\right) \text { є тим головним фактором, що визначає таку } \\
\text { складову (концепт) ЛІІ, як наявність готових правил лікування даної } \\
\text { конкретної нозології }\left(X_{2}^{d}\right) \text {. }\end{array}$ \\
\hline $\boldsymbol{R}_{l_{2}}\left(X_{2}^{d}\right)=X_{3}^{d} \Leftrightarrow \boldsymbol{R}_{l_{2}}\left(X_{2}^{d}, X_{3}^{d}\right)$ & $\begin{array}{l}\text { Відповідно до правил ведення ЛП }\left(X^{d}{ }_{2}\right) \text { визначається наступний набір: } \\
X^{d}{ }_{3}-\text { параметри об'єкта, на який буде здійснюватися ЛВ }\end{array}$ \\
\hline $\boldsymbol{R}_{I_{3}}\left(X_{2}^{d}\right)=X_{4}^{d} \Leftrightarrow \boldsymbol{R}_{I_{3}}\left(X_{2}^{d}, X_{4}^{d}\right)$ & $X_{4}^{d}-$ вимоги до структурних складових \\
\hline $\boldsymbol{R}_{l_{4}}\left(X_{2}^{d}\right)=X_{5}^{d} \Leftrightarrow \boldsymbol{R}_{1_{4}}\left(X_{2}^{d}, X_{5}^{d}\right)$ & $X^{d}{ }_{5}-$ вимоги до персоналу, що здійснює ЛП \\
\hline $\boldsymbol{R}_{1_{5}}\left(X_{2}^{d}\right)=X_{6}^{p} \Leftrightarrow \boldsymbol{R}_{1_{5}}\left(X_{2}^{d}, X_{6}^{p}\right)$ & $X_{6}^{p}-$ правила проведення процесу ЛВ \\
\hline $\begin{array}{l}\boldsymbol{R}^{-1}{ }_{1_{6}}\left(X^{d}{ }_{3}\right)=X^{p}{ }_{6} \Leftrightarrow \boldsymbol{R}^{-1}{ }_{{ }_{6}}\left(X^{d}{ }_{3},\right. \\
\left.X^{p}{ }_{6}\right) \\
\boldsymbol{R}^{-1}{ }_{1_{7}}\left(X^{d}{ }_{4}\right)=X_{6}^{p} \Leftrightarrow \boldsymbol{R}^{-1}{ }_{1_{7}}\left(X^{d}{ }_{4},\right. \\
\left.X^{p}{ }_{6}\right) \\
\boldsymbol{R}^{-1}{ }_{1_{8}}\left(X^{d}{ }_{5}\right)=X_{6}^{p} \Leftrightarrow \boldsymbol{R}^{-1}{ }_{1_{8}}\left(X^{d}{ }_{5},\right. \\
\left.X^{p}{ }_{6}\right)\end{array}$ & Процес здійснення ЛВ $\left(X_{6}^{p}\right)$ ініціюеться появою концептів: $X_{3}^{d}, X^{d}{ }_{4}, X^{d}{ }_{5}$ \\
\hline $\boldsymbol{R}_{1_{9}}\left(X_{6}^{p}\right)=X_{7}^{d} \Leftrightarrow \boldsymbol{R}_{1_{9}}\left(X_{6}^{p}, X^{d}{ }_{7}\right)$ & $\begin{array}{l}\text { У результаті здійснення процесу проведення ЛВ }\left(X_{6}^{p}\right) \text { лікар отримує } \\
\text { результати вимірів параметрів }\left(X^{d}\right) \text {. }\end{array}$ \\
\hline 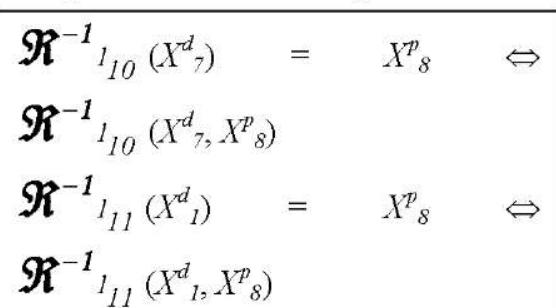 & $\begin{array}{l}\text { Процес моніторингу }\left(X^{p}\right) \text { ініціюється одержанням результатів вимірів } \\
\text { параметрів }\left(X^{d}{ }_{7}\right) \text { і керується метою ЛП }\left(X^{d}{ }_{1}\right) \text {. }\end{array}$ \\
\hline $\boldsymbol{R}_{1_{12}}\left(X^{p_{8}}\right)=X_{9}^{d} \Leftrightarrow \boldsymbol{R}_{1_{12}}\left(X_{8}^{p}, X_{9}^{d}\right)$ & $\begin{array}{l}\text { При кожній перевірці }\left(X^{p}{ }_{8}\right) \text { лікар робить відповідні висновки }\left(X^{d}{ }_{9}\right) \text {. } \\
\text { Лікувальний процес закінчується в тому випадку, якщо лікар отримує } \\
\text { очікувані висновки. }\end{array}$ \\
\hline
\end{tabular}

Вибір спрямованості відносин при описі онтології визначають експерти. Із запропонованих варіантів спрямованості експертами був зроблений вибір, що представлений нижче.

На другому рівні відносин представимо набори взаємодіючих концептів у такий спосіб.

Як було показано раніше, наявність готових правил ведення лікування конкретної нозології $\left(X^{d}{ }_{2}\right) \epsilon$ тим головним фактором, що визначає такі складові (концепти) ЛП, як: $\mathrm{X}_{3}{ }_{3}$ - параметри об'єкта, на які буде здійснюватися ЛВ; $X_{4}^{d}$ - вимоги до структурних складових; $X^{d}{ }_{5}$ - вимоги до персоналу, що здійснює ЛП; $X_{6^{-}}^{p}$ правила проведення ЛП:

$$
\begin{aligned}
& \mathscr{R}_{1_{2}}\left(X_{2}^{d}\right)=X_{3}^{d} \Leftrightarrow \mathscr{R}_{1_{2}}\left(X_{2}^{d}, X^{d}{ }_{3}\right) \\
& \boldsymbol{R}_{1_{3}}\left(X^{d}{ }_{2}\right)=X^{d}{ }_{4} \Leftrightarrow \boldsymbol{R}_{1_{3}}\left(X^{d}{ }_{2}, X^{d}{ }_{4}\right)
\end{aligned}
$$

$$
\begin{aligned}
& \Re_{1_{4}}\left(X^{d}{ }_{2}\right)=X^{d}{ }_{5} \Leftrightarrow \Re_{1_{4}}\left(X^{d}{ }_{2}, X^{d}{ }_{5}\right) \\
& \boldsymbol{R}_{1_{5}}\left(X^{d}{ }_{2}\right)=X^{p}{ }_{6} \Leftrightarrow \boldsymbol{R}_{1_{5}}\left(X^{d}{ }_{2}, X^{p}{ }_{6}\right)
\end{aligned}
$$

Але, з урахуванням спрямованості онтології, у цьому випадку виходить "розбіжне" розгалуження, тобто один концепт через відносини породжує ряд інших, незв'язаних концептів. Об'єднання даного кластера в онтологію більш високого рівня у цьому випадку, не відбувається.

Як було зазначено раніше, процес здійснення ЛВ $\left(\mathrm{X}_{6}^{\mathrm{p}}\right.$ ) ініціюється появою концептів $\mathrm{X}_{3}^{\mathrm{d}}$ (параметри об'єкта, на які буде здійснюватися ЛВ), $\mathrm{X}_{4}^{\mathrm{d}}$ (вимоги до структурних складових) $\mathrm{i}^{\mathrm{d}}{ }_{5}$ (вимоги до персоналу, що здійснює ЛП).

$$
\Re^{-1}{ }_{1_{6}}\left(X_{3}^{d}\right)=X_{6}^{p} \Leftrightarrow \Re^{-1}{ }_{16}\left(X^{d}{ }_{3}, X^{p}{ }_{6}\right)
$$




$$
\begin{aligned}
& \Re^{-1}{ }_{1_{7}}\left(X^{d}{ }_{4}\right)=X_{6}^{p} \Leftrightarrow \Re^{-1}{ }_{1_{7}}\left(X^{d}{ }_{4}, X_{6}^{p}\right) \\
& \Re^{-1}{ }_{1_{8}}\left(X_{5}^{d}\right)=X_{6}^{p} \Leftrightarrow \Re^{-1}{ }_{1_{8}}\left(X^{d}{ }_{5}, X_{6}^{p}\right)
\end{aligned}
$$

У цьому випадку $є$ присутнім "збіжність" відносин. Звідси відношення другого рівня можна записати як:

$$
\Re_{2_{2}}\left(\Re^{-1}{ }_{1_{6}}\left(X^{d}{ }_{3}, \quad X_{6}^{p}\right), \quad \Re^{-1}{ }_{1_{7}}\left(X^{d}{ }_{4}, \quad X_{6}^{p}\right),\right.
$$

$\left.\mathfrak{R}^{-1}{ }_{1_{8}}\left(X^{d}, X^{p}\right), X_{6}^{p}\right)$

Як було визначено раніше, процес моніторингу $\left(X^{p}{ }_{8}\right)$ враховує мету ЛП - $\left(X^{d}{ }_{1}\right)$ і він же ініціюється результатами вимірів параметрів $\left(X^{d}{ }_{7}\right)$ :

$$
\begin{aligned}
& \Re^{-1}{ }_{10}\left(X^{d}{ }_{7}\right)=X^{p}{ }_{8} \Leftrightarrow \Re^{-1}{ }_{10}\left(X^{d}{ }_{7}, X^{p}{ }_{8}\right) \\
& \Re^{-1}{ }_{{ }_{11}}\left(X^{d}\right)=X^{p}{ }_{8} \Leftrightarrow \Re^{-1}{ }_{{ }_{11}}\left(X^{d}{ }_{1}, X_{8}^{p}\right)
\end{aligned}
$$

Звідси відношення другого рівня можна записати як: $\mathfrak{R}_{2_{3}}\left(\Re_{{ }_{10}}^{-1}\left(X^{d}, X^{p}{ }_{8}\right), \Re^{-1}{ }_{11}\left(X_{1}^{d}, X^{p}{ }_{8}\right), X_{8}^{p}\right)$

Таким чином, повну онтологію ЛП можна описати наступною послідовністю: $\mathfrak{R}_{3_{1}}=\left(\Re_{1_{0}}^{-1}, \mathfrak{R}_{1_{1}}, \mathfrak{R}_{1_{2}}\right.$, $\mathfrak{K}_{1_{3}}, \mathfrak{R}_{1_{4}}, \mathfrak{K}_{1_{5}}, \mathfrak{R}_{1_{6}}^{-1}, \mathfrak{K}_{1_{7}}^{-1}, \mathfrak{R}_{1_{8}}^{-1}, \mathfrak{R}_{1_{9}}$,

\section{Література}

1. Межуев В.И. Моделирование свойств операционной системы реального времени OpenComRTOS при помощи OWL-DL онтологий / В.И. Межуев // Збірник наукових праць ДонНТУ: серія «Інформатика, кібернетика та обчислювальна техніка». - 2009. - Вип. 10 (153). - С. 39-46.

2. Eric Verhulst. An Industrial Case: Pitfalls and Benefits of Applying Formal Methods to the Development of a NetworkCentric RTOS / Eric Verhulst, Gjalt de Jong, Vitaliy Mezhuyev

$$
\begin{aligned}
& \left.\mathfrak{R}^{-1}{ }_{10}, \Re^{-1}{ }_{11}, \Re_{1_{12}}\right) \text {, або } \mathfrak{R}_{3_{1}}\left(\Re^{-1}{ }_{1_{0}}\left(X^{p}{ }_{0}, X^{d}{ }_{1}\right)\right. \text {, } \\
& \Re_{1_{1}}\left(X^{d}{ }_{1}, X^{d}{ }_{2}\right), \Re_{1_{2}}\left(X^{d}{ }_{2}, X^{d}{ }_{3}\right), \Re_{1_{3}}\left(X^{d}{ }_{2}, X^{d}{ }_{4}\right) \text {, } \\
& \Re_{1_{4}}\left(X^{d}{ }_{2}, X^{d}{ }_{5}\right), \Re_{1_{5}}\left(X^{d}{ }_{2}, X^{p}{ }_{6}\right), \Re_{2_{2}}\left(\Re ^ { - 1 } { } _ { 1 _ { 6 } } \left(X^{d}{ }_{3}\right.\right. \text {, } \\
& \left.\left.X^{p}{ }_{6}\right), \Re^{-1}{ }_{1_{7}}\left(X^{d}{ }_{4}, X^{p}{ }_{5}\right), \Re^{-1}{ }_{1_{8}}\left(X^{d}{ }_{5}, X^{p}{ }_{6}\right), X_{6}^{p}\right), \Re_{1_{9}}\left(X^{p}{ }_{6},\right. \\
& \left.X^{d}\right), \Re_{2_{3}}\left(\Re^{-1}{ }_{10}\left(X^{d}{ }_{7}, X^{p}{ }_{8}\right), \Re^{-1}{ }_{11}\left(X^{d}{ }_{1}, X^{p}{ }_{8}\right), X^{p}{ }_{8}\right) \text {, } \\
& \left.\Re_{1_{12}}\left(X^{p}{ }_{8}, X^{d}\right)\right) \text {. }
\end{aligned}
$$

Висновки. Набори готових онтологічних схем дадуть можливість розроблювачам, користуючись універсальними структурами, описувати галузі медичних знань. Подібна структурованість надає певні гарантії узгодженості процедурних і декларативних концептів предметної галузі як в межах дисципліни, так і на міждисциплінарному рівні. Це, у свою чергу, повинно привести до мінімізації перекручувань у сприйнятті, інтерпретації й передачі медичних знань.

Подібні описи також можуть бути основою для розробки медичних стандартів, що дозволить, в кінцевому рахунку, підвищити якість медичної допомоги, що надається.

// Lecture Notes in Computer Science. FM 200S: Formal Methods (Springer Berlin / Heidelberg). - 2008. - P. 411-418. 3. Никоненко А. А. Обзор баз знаний онтологического типа/ А.А.Никоненко // Искусственный интеллект.- № 4.- 2009.C. 208-219.

4. Онтологии и тезаурусы: учебное пособие. / [Соловьев В. Д., Добров Б.В., Иванов В.В. и др]. - Казань; Москва, 2006. - 173 c. 